\title{
Fibrin Scaffolds Designing in order to Human Adipose-derived Mesenchymal Stem Cells Differentiation to Chondrocytes in the Presence of TGF- $\beta 3$
}

\author{
Mohsen Sheykhhasan, Reza Tabatabaei Qomi, Mahdieh Ghiasi \\ Stem Cell laboratory, The Academic Center for Education, Culture and Research, Qom Branch, Qom, Iran
}

\begin{abstract}
Background and Objectives: One of the most cellular source used for cartilage tissue engineering are mesenchymal stem cells (MSCs). In present study, human MSCs were used as cellular source. Since scaffold plays an important role in tissue engineering the aim of this study is to assess fibrin scaffold ability in chondrogenic differentiation of adipose-derived mesenchymal stem cells (ADMSCs).

Methods: ADMSCs were isolated and cultured in DMEM medium supplemented with 10\% FBS. Also ADMSCs expanded and characterised by flow cytometry. ADMSCs expressed CD44, CD90, CD105 but not CD34. After trypsinization, cells were entered within the fibrin scaffold. Then, chondrogenic medium was added to the scaffold. Seven days after cell culture, cell viability and proliferation were assessed by MTT test. Finally, 14 days after the ending of chondrogenic differentiation, analysis of chondrogenic genes expression was evaluated by RT-PCR and Real time PCR. Also, formation and development of chondrocyte cells was analysed by histological and immunohistochemistry evaluations. Results: Viability and proliferation as well as chondrogenic genes expression within fibrin scaffold increased significantly compared with control group (cells free scaffold). Also, histological and immunohistochemistry evaluation showed that chondrocyte cells and collagen type II are formed on fibrin scaffold.

Conclusions: Fibrin is a suitable scaffold for chondrogenic differentiation of ADMSCs.
\end{abstract}

Keywords: Tissue Engineering, Adipose-Derived Mesenchymal Stem Cells (ADMSCs), Chondrogenic Differentiation, Fibrin

\section{Introduction}

Cartilage defects repair have been considered extremely difficult due to very slow turnover at the cellular and molecular level and also the low regenerative capacity of articular chondrocytes (1-4). This restricted self-repair capa-

\footnotetext{
Accepted for publication May 9, 2015, Published online November 30, 2015 Correspondence to Mahdieh Ghiasi

Stem Cell laboratory, The Academic Center for Education, Culture and Research, Qom Branch, Qom 3713189934, Iran

Tel: +98-25-32700155, Fax: +98-25-32700154

E-mail: m.ghiasi@acecr.ac.ir

(c) This is an open-access article distributed under the terms of the Creative Commons Attribution Non-Commercial License (http://creativecommons.org/ licenses/by-nc/4.0/), which permits unrestricted non-commercial use, distribution, and reproduction in any medium, provided the original work is properly cited.
}

bility of the cartilage forced scholars to develop new technologies and appropriate biomaterials to advance tissue integration. In recent years, cartilage regeneration has obtained nice success by method of tissue engineering (5). The tissue engineering has created as a new approach for repairing damaged or disabled tissues/organs such as cartilage, bone and skin (5-7). During tissue engineering the healing capacity of the sick is increased, thereby damaged tissues can be repaired and returned its natural functions $(5,6)$. An appropriate cell source is a fundamental requirement for a successful tissue engineering application $(5,7)$. Cellular sources that have been used extensively are chondrocytes and MSCs (6). The select of cell type defines the strategy of cartilage tissue engineering (5). There are obstacles to the chondrocytes-based cell therapy (6). Recent studies have demonstrated that the proliferative capacity 
of the terminal differentiated chondrocytes was decreased with in vitro expansion (2). In addition, MSCs have advantages over chondrocytes, since they can be obtained in autologous form in a minimally invasive procedure (4). While the procedure required to harvest autologous cells may initiate joint degeneration (3). Due to this reason, many efforts are being done to use MSCs for cartilage tissue engineering (4). MSCs are multipotent cells which are found in bone marrow, muscle, skin and fat tissue (8). These cells have ability to differentiation into tissues of mesenchymal origin, includin muscle, bone, tandem, adipose tissue and cartilage (9). Lately, research has demonstrated that stem cells derived from human adipose tissue contain multipotent progenitor cells that can differentiate into osteogenic, chondrogenic, myogenic, and neurogenic cells when induced by the suitable biological factors in vitro (10-12). The use of ADMSCs in cartilage tissue engineering requires a lot of research in the field of cell scaffolds (4). The scaffold plays an important role as physical suport and template in tissue engineering by supplying a $3 \mathrm{D}$ substrate for cell growth and tissue regeneration $(2,13)$. The ideal scaffold should have mechanical properties like tissue, display immunologic integrity, and support cell adhesion, migration and differentiation (14). Also, scaffold should not initiate an immunological or 'foreign body' response in the sick (15). Scaffolds can be made of natural materials, of synthetic materials or both (hybrid scaffolds) $(16,17)$. Natural materials have physiological activities, including cell adhesion and biodegradability (16). Fibrin is one of the natural materials that have high potential for use in tissue engineering $(17,18)$. It can be isolated from the patient blood and used as an autologous scaffold, without the potential risk of a foreign body reaction or infections $(17,19,20)$. In addition, fibrin plays a special role in angiogenesis (21). This is useful for tissue engineering, because one of the main problems in engineered tissues is the limited blood supply (22). During wound healing the fibrin provides an appropriate environment for angiogenesis and thereby recovery of the blood supply $(23,24)$. Also, fibrin is used in stem cell research (19). Because its cell adhesive properties, biocompatibility and biodegradation (18). Upon contact with fibrin, cells will gradually replace the fibrin scaffold by an adult tissue-specific extracellular matrix (4). According to, these features make fibrin an interesting and widely used protein for tissue engineered scaffolds (17). also, The differentiation medium required to induce chondrogenic differentiation of ADMSCs usually contains a cocktail of growth factors (12). Transforming growth factor- $\beta$ (TGF- $\beta 3$ ) is considered as the most important component (12). TGF- $\beta 3$ has been regarded as the most powerful chondrogenic growth factor, which induces significant chondrogenic phenotype of ASCs both in vitro and in vivo $(4,12)$.

The aim of this study was to evaluate the ability of fibrin as a natural scaffold for Cell differentiation into cartilage tissue and protect them for growth and expand their in vitro.

\section{Materials and Methods}

\section{Materials}

Dulbecco's minimum essential medium (DMEM) for cell culture was purchased from Sigma and fetal bovine serum (FBS) and penicillin-streptomycin were purchased from Gibco (BRL, Gaithersburg, MD, USA).

\section{Isolation and culture of human ADMSCs}

Adipose tissue was harvested from patients by elective surgery (liposuction) and transferred to the laboratory under sterilized condition. Previously, consent was obtained from each patient. Adipose tissue mechanically chopped and washed with PBS (Sigma-Aldrich, St. Louis, MO, USA). Afterward, it was digested with $5 \mathrm{mg} / \mathrm{ml}$ collagenase type I (Sigma-Aldrich, St. Louis, MO, USA) at $37^{\circ} \mathrm{C}$ for $45 \sim 60 \mathrm{~min}$. Then, the cell solution was centrifuged at $1800 \mathrm{rpm}$ for $10 \mathrm{~min}$. At the end, the supernatant was removed and the resultant pellet was resuspended in medium contained DMEM supplemented with 10\% FBS, 100 $\mathrm{U} / \mathrm{ml}$ penicillin/streptomycin and then cultured in a humidified atmosphere of $95 \%$ air, $5 \% \quad \mathrm{CO} 2$ at $37^{\circ} \mathrm{C}$. Medium was replaced every 3 days. When the cells reached 90\% confluence at passage 2, ADMSCs were harvested with $0.25 \%$ trypsin and used at a density of $1 \times 10^{6}$ cells for any scaffold.

\section{Confirmation of Human Mesenchymal Stem/Stromal Cell Identity by Analysis of MSC Marker Expression}

The expression of surface markers of MSCs including CD34, CD44, CD90, and CD105 was tested with flow cytometry technique. Upon reaching $95 \%$ confluence in culture, the cells were resuspended in phosphate buffered saline at $1 \mathrm{million} / \mathrm{ml} .100 \mu 1$ of this cell suspension is taken in each Falcon the Fluorescence Activated Cell Sorter (FACS) tubes. Monoclonal antibodies against human CD44 (abcam, Cambridge, USA), CD90 (abcam, Cambridge, USA), CD105 (abcam, Cambridge, USA) and CD34 (abcam, Cambridge, USA), were used. Also, the appropriate amount of conjugated antibody or isotype control is added to each FACS tube. Tubes are incubated at room temperature in the dark for 15 20 min. After the incubation, the cells 
are washed with $2 \mathrm{ml}$ of phosphate buffered saline $\left(\mathrm{Ca}^{2+}\right.$ free) and run through a BD FACS Calibur flow cytometer (Becton Dickinson, California, USA). Typically for each tube, 500,000 cells are collected and the data are analyzed using Cell Quest version 3.0.1 software (Becton Dickinson, California, USA). the positive expression was described as the level of fluorescence greater than $99 \%$ of the corresponding unstained cell sample.

\section{Preparation of fibrinogen and thrombin}

Fibrinogen and Fresh frozen plasma solutions (FFP) were obtained from Iranian Blood Transfusion Organization. FFP was thawed in water bath at $37^{\circ} \mathrm{C}$. Then $15 \mathrm{~mL}$ of it was mixed with $10 \mathrm{~mL}$ of calcium glucuronate (mid 5:3 Ratio). The obtained solution was incubated for $1 \mathrm{~h}$ at $37^{\circ} \mathrm{C}$ and subsequently centrifuged at $2200 \mathrm{rpm}$ for 10 min. The supernatant was collected as thrombin. Fibrinogen and thrombin solutions were prepared for use as cell culture. To this end, the adipose tissue-derived stem cells at a concentration of $5 \times 10^{6}$ cells per $\mathrm{ml}$ were dissolved within thrombin and subsequently fibrinogen was added to them. Then the scaffolds in chondrogenic medium containing DMEM-high glucose along with $50 \mu \mathrm{g} / \mathrm{mL}$ ascorbate 2- phosphate, $1 \%$ insulin-transferin-selenium (SigmaAldrich, St. Louis, MO, USA), dexamethasone $100 \mathrm{nM}$ (Sigma-Aldrich, St. Louis, MO, USA), $50 \mathrm{mg} / \mathrm{mL}$ FBS, $5 \mu \mathrm{g} / \mathrm{mL}$ linoleic acid (Sigma-Aldrich, St. Louis, MO, USA), $1 \%$ penicillin/streptomycin and $10 \mathrm{ng} / \mathrm{ml}$ transforming growth factor- $\beta_{3}$ (Sigma-Aldrich, St. Louis, $\mathrm{MO}$, USA) was placed in the incubator $\left(37^{\circ} \mathrm{C}, 5 \% \mathrm{CO} 2\right.$, $99 \%$ humidity) for 14 days.

\section{Cell viability measurement}

At first, the human adult stem cells were seeded within the scaffolds in chondrogenic medium and then were in- cubated for 7 days $\left(37^{\circ} \mathrm{C}, 5 \% \mathrm{CO} 2,99 \%\right.$ humidity). Cells viability and proliferation were assessed by MTT (3-(4, 5-dimethyl) thiazol-2-yl-2, 5-dimethyl tetrazolium bromide, $5 \mathrm{mg} / \mathrm{ml}$ ). Compound MTT was added per well after removing chondrogenic medium and incubated at $37^{\circ} \mathrm{C}$ for $4 \mathrm{~h}$. Then, the medium was discarded and intracellular formazan was solubilized by adding $400 \mu 1$ of dimethyl sulphoxide. The absorbance of each well was read at 570 $\mathrm{nm}$ with immunosorbent assay (ELISA) plate reader (Hiperion MPR4, Germany). The ADMSCs without scaffold in MTT assay were also applied as controls and the data was subtracted from measured values. This assay was performed in triplicate.

\section{RT-PCR analysis}

Total RNA was isolated from adipose derived mesenchymal stem cells using Trizol ${ }^{\mathbb{R}}$ according to the manufacturer's protocol (Invitrogen Life Technologies, Burlington, Ontario, Canada). $\beta$-actin was amplified as an control. primers of cartilage-specific genes were designed as follows utilizing primer 3 program that it's primer sequences is shown in Table 1.

After synthesis of single stranded cDNA, RT-PCR was performed. The expression of several cartilage-specific genes (type I and II collagen, SOX9 and aggrecan) was analyzed by RT-PCR.

For this purpose, each reaction was analyzed by $1.5 \%$ agarose gel electrophoresis, and visualized by ethidium bromide staining and the images were analyzed by the Gel Doc imaging system (Bio-Rad, Hercules, CA, USA).

\section{Expression analysis of chondrogenic genes by Real time PCR}

Expression of cartilage-specific markers (type I and II collagen, Sox9 and aggrecan) was evaluated of 14 days af-

Table 1. Primer sequences used for RT-PCR and Real-time PCR

\begin{tabular}{|c|c|c|}
\hline Primer Name & Sequences $\left(3^{\prime} \rightarrow 5^{\prime}\right)$ & Refrence \\
\hline Collagen type I ( COL2A1) Forward & CGTCCAGATGACCTTCCTACG & NM_001844 \\
\hline Colla Collagen type I ( COL2A1) Reverse & TGAGCAGGGCCTTCTTGAG & \\
\hline Collagen type II (COL1A2) Forward & CAGGAAACAGCTATGACC & NM_000089 \\
\hline Collagen type II (COL1A2) Reverse & СТАСТСТСАGСССAGGAGGTССТG & \\
\hline Aggrecan (ACAN) Forward & AGGCAGCGTGATCCTTACC & NM_001135 \\
\hline Aggrecan (ACAN) Reverse & GGССТСТССАGTСTСАТTСТC & \\
\hline SOX9 Forward & GTACCCGCACTTGCACAAC & NM_000346 \\
\hline SOX9 Reverse & TCTCGCTCTCGTTCAGAAGTC & \\
\hline GAPDH Forward & СGСтСтСтGСтССтССтGтт & NM_001256799 \\
\hline GAPDH Reverse & CCATGGTGTCTGAGCGATGT & \\
\hline$\beta$-Actin Forward & AATCTGGCACCACАССТTСТАС & NM_001101 \\
\hline$\beta$-Actin Reverse & CATCTTCCACACCACGGTCTAA & \\
\hline
\end{tabular}


ter the ending of chondrogenic differentiation. The scaffolds were degraded within liquid nitrogen and then total RNA was extracted of all samples using an AccuZol ${ }^{\mathrm{TM}}$ (bioNEER, Daedeok-gu, Daejeon, Korea) in accordance with the manufacturer's protocol. Afterwards, the reverse transcription of RNA was carried to produce a complementary DNA (cDNA) using the AccuPower ${ }^{\mathbb{R}}$ RT PreMix (bioNEER, Daedeok-gu, Daejeon, Korea). Real-time PCR was performed using SYBRGreen PCR Master Mix and Rotor-Gene $^{\mathrm{TM}} 6000$ Series Software version 1.7.65 (Corbett Life Science, Australia), and primers of each gene were designed as follows utilizing primer 3 program that it's primer sequences is presented in Table 1:

The reaction was initiated by heating to $95^{\circ} \mathrm{C}$ for 15 min., followed by 40 cycles of elongation at $59^{\circ} \mathrm{C}$ for 30 sec and denaturation at $95^{\circ} \mathrm{C}$ for $15 \mathrm{sec}$.

Target gene was normalized based on glyceraldehyde 3-phosphate dehydrogenase reference gene. The level of expression of each target gene was calculated using $2^{-\triangle \Delta \mathrm{Ct}}$.

\section{Histological Examination}

14 days after the chondrogenic induction, samples of ADSCs that were seeded on fibrin glue scaffolds and control cultures were rinsed thoroughly with PBS and fixed in $10 \%$ formalin for 24 hours. Then, samples after the dehydration with ethanols, were embedded in parafin and sectioned at $5 \mu \mathrm{m}$ thickness. Finally, samples were stained with hematoxylin/eosin.

\section{Immunohistochemistry}

Formaldehyde-fixed tissues were used for the immunohistochemical analysis. Immunohistochemistry was performed using the streptavidin-biotin method, with a SAB-PO kit (Nichirei Co. Ltd., Tokyo, Japan). For immunohistochemical analysis, collagen type II antibody was used as a first antibody. Immunohistochemistry with the collagen type II antibody was performed using the same procedure (streptavidin-biotin method) on freshly frozen tissue sections. Sections $5 \mathrm{~mm}$ thick were cut using a cryostat microtome (Bright, Huntingdon, UK), and dried at room temperature for $30 \mathrm{~min}$. After fixation in acetone for $10 \mathrm{~min}$, the sample sections were treated with $3 \%$ hydrogen peroxide in methanol to eliminate endogenous peroxidase activity.

\section{Results}

\section{Expression of cell surface markers}

As reported in Fig. 2, ASCs identified positive expersion for CD44, CD90, CD105 and negative for CD34, at passage 3 (Fig. 1).

\section{Cell proliferation and viability}

Cell viability and proliferation were assessed by MTT
A

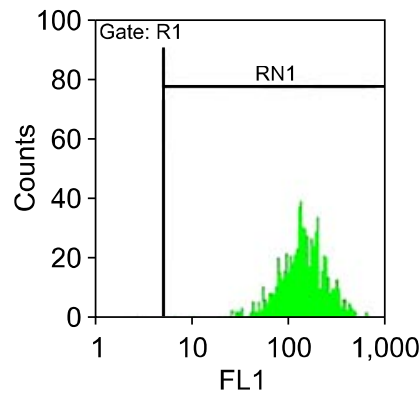

C

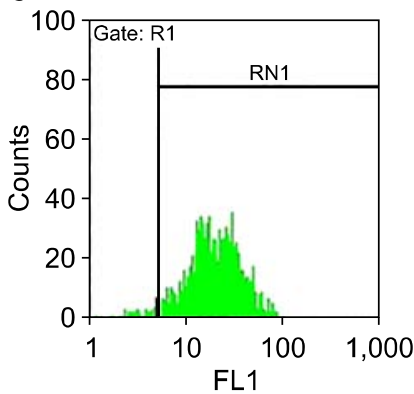

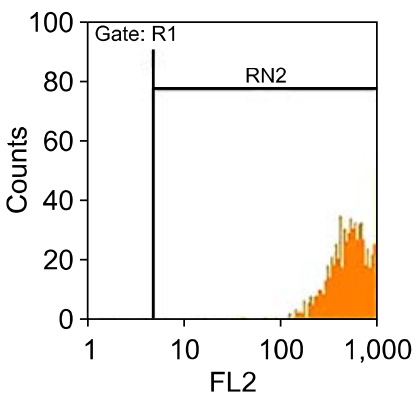

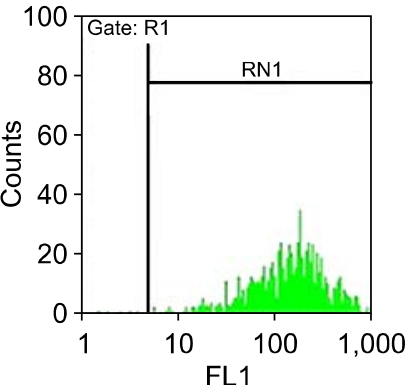

D

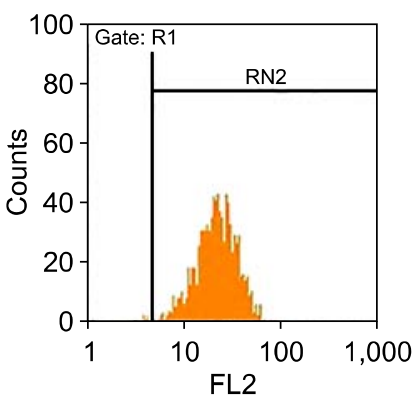

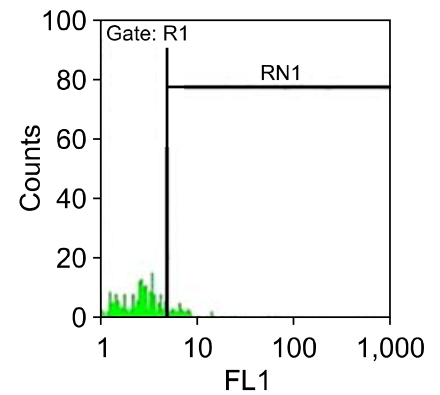
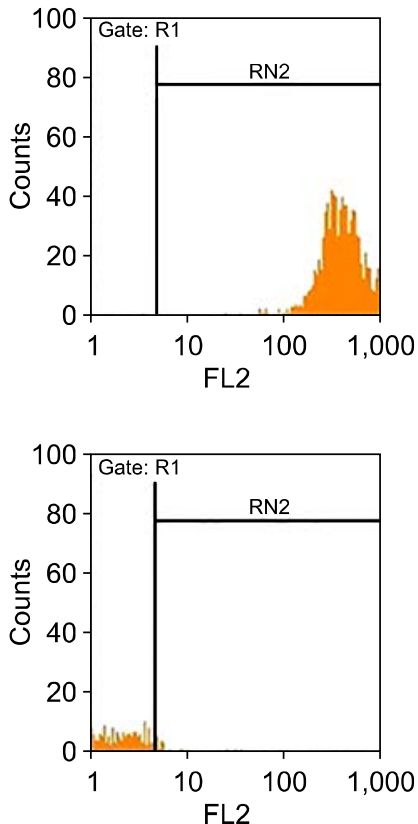

Fig. 1. Flow cytometeric analysis for the determination of the surface markers of MSCs expression. (A) CD44, (B) CD90, (C) CD105 and (D) CD34. 
at day 7. Our study demonstrated that the fibrin scaffold significantly increased viability and proliferation cells compared with control group (cells free scaffold) $(\mathrm{p}<0.05)$ (Fig. 2).

\section{The morphology of adipose derived mesenchymal stem cells}

In the study of living and not stained cells using phase contrast microscope, they were determined as small cells with little cytoplasm and elliptic central core. Also, in the primary levels of culture they had a few short cytoplasmic frills. Arriving at the third passage, homogeneity and uniformity in culture of isolated cells was fully determined (Fig. 3).

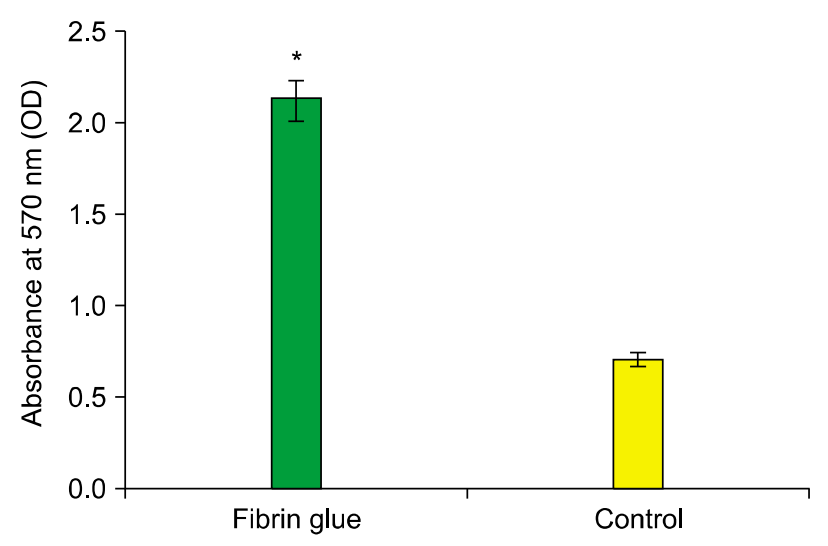

Fig. 2. The comparison of cell viability between MSCs embedded in fibrin scaffold and control group.

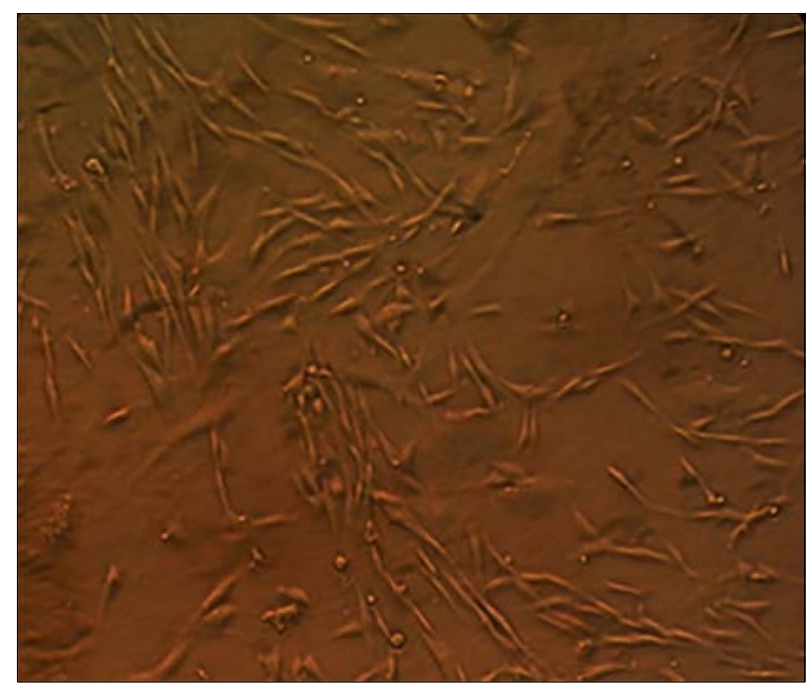

Fig. 3. Image produced by invert microscope of living mesenchymal stem cells isolated from human adipose tissue which spindle cells in the third passage are visible. $\times 40$.

\section{Chondrogenic differentiation}

The mRNA expression of collagen I and II, SOX9 and aggrecan was tested to evaluate the differentiated status of ADMSCs on the fibrin scaffold after 14 days of chondrogenic induction. Statistical analysis has shown a significant difference in the expression of all genes (type I and II collagen, SOX9 and aggrecan) between cell/fibrin and ADMSCs $(\mathrm{p}<0.05)$ (Fig. 4 and 5).

\section{Histological evaluation}

With hematoxyline and eosin, the present of chondrocyte in the differentiated cell on the fibrin glue scaffold were determined after 14 days (Fig. 6).

\section{Immunohistochemistry analysis}

The finding of this study indicate that the accumulation of type II collagen around the cells, in fibrin gel, gradually appeared over the two weeks after culture and differentiation period (Fig. 7).

\section{Statistical Analysis}

ANOVA was used to analysis of viability and chondrogenic differentiation of cells in fibrin glue scaffolds. Data is presented as means plus or minus one standard error

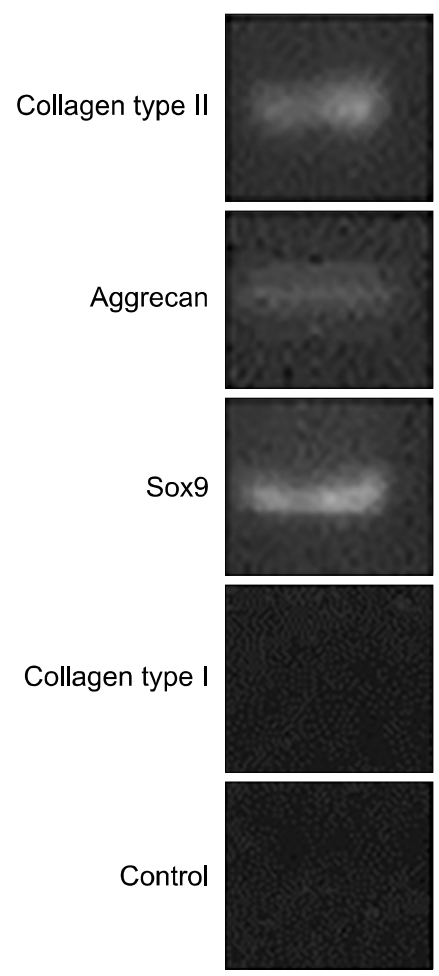

Fig. 4. The analysis of collagen Type II, Aggrecan and SOX9 genes expression in cell/fibrin using RT-PCR method. 

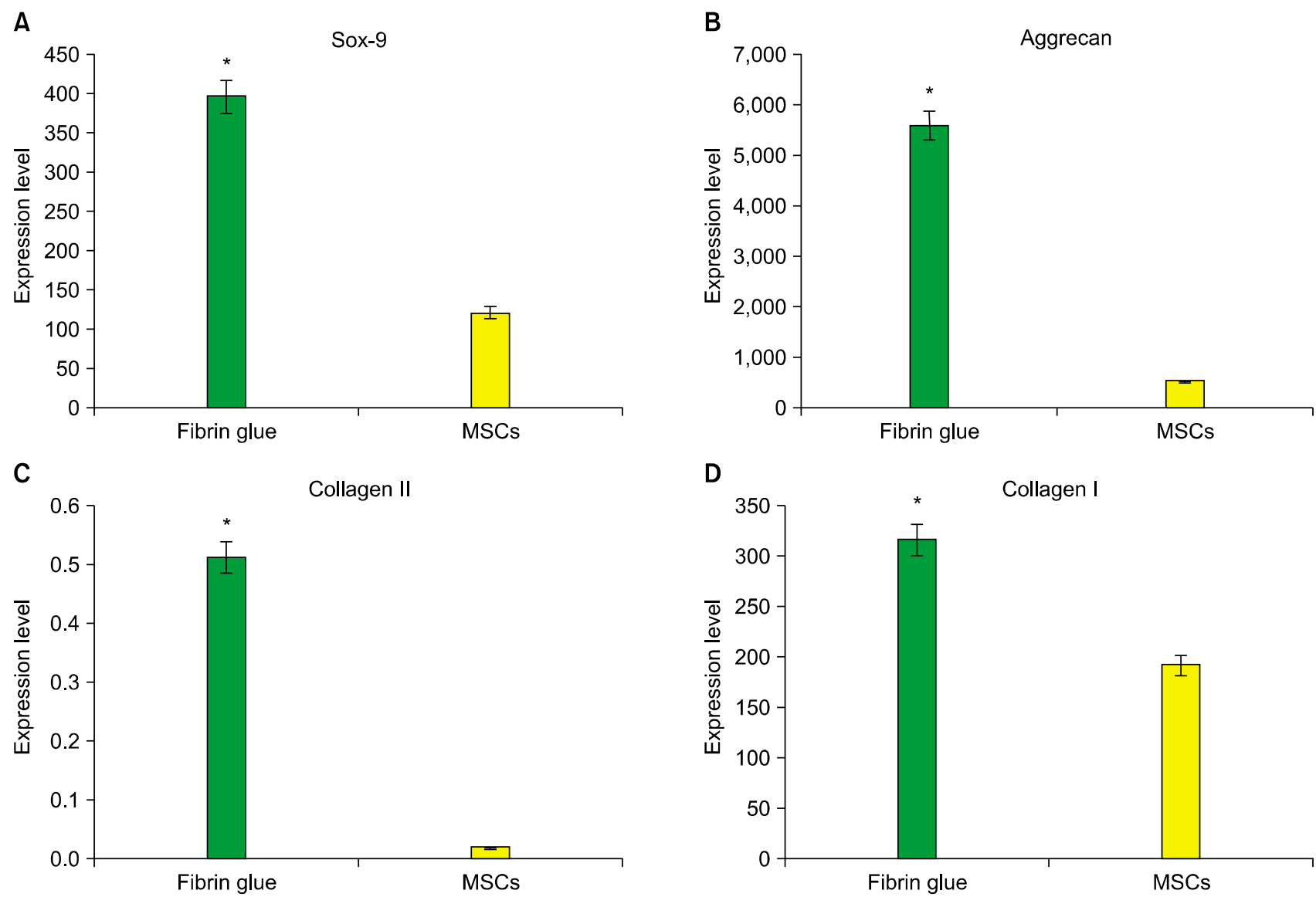

Fig. 5. The expression of collagen I, Aggrecan, SOX9 and Collagen II in cell/fibrin vs. MSCs.
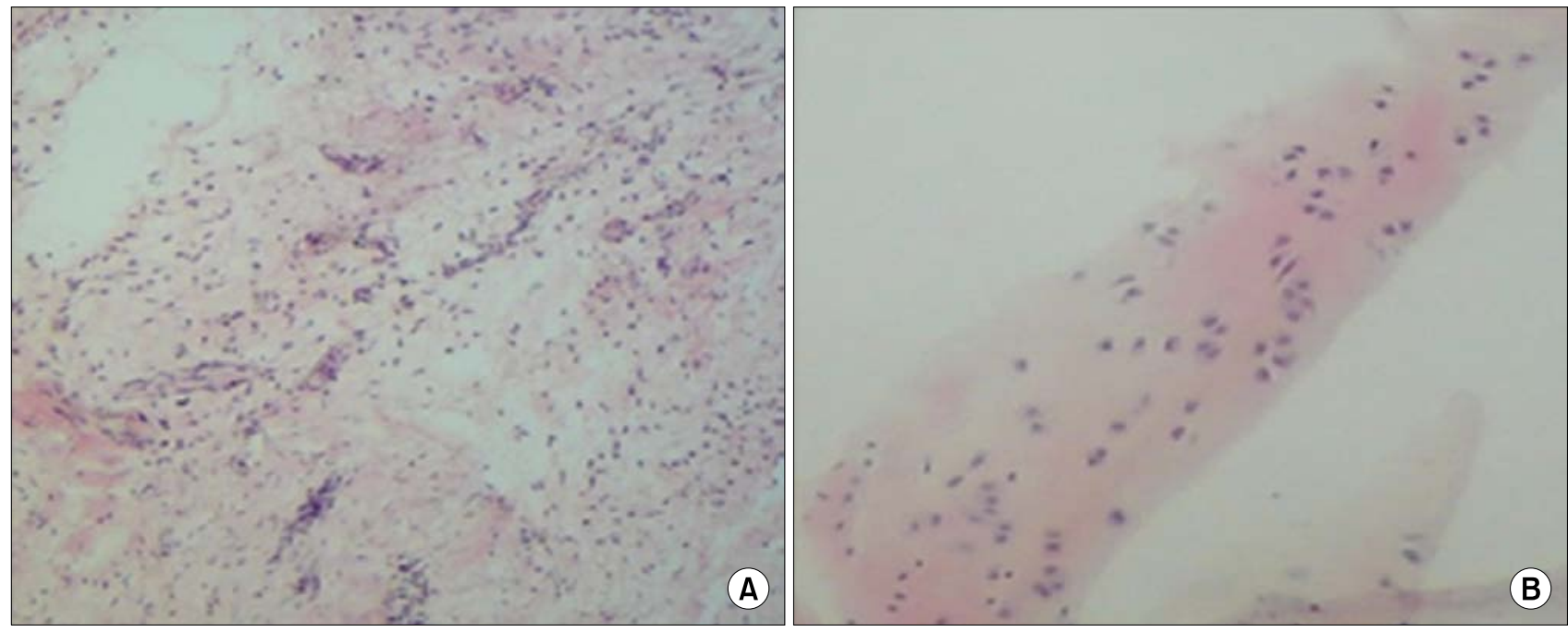

Fig. 6. Histological examination of the ADMSCs using haematoxylin and eosin staining. After 4 weeks there was significant cartilage formation with high cell density in ADMSCs seeded on the Fibrin glue scaffold (original magnification $\times 10)(A)$. Staining of native cartilage used as control with hematoxylin/eosin is demonstrated in (B) ( $\times 50$ magnification). 


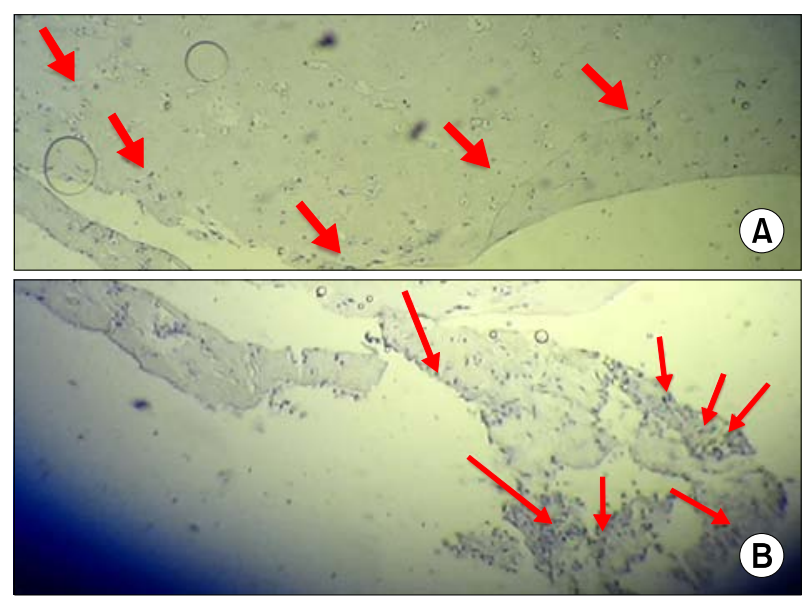

Fig. 7. The analysis of collagen type II antibody (arrowheads) in cell/fibrin (A) and control group (B) using immunohistochemistry evaluation.

of the mean throughout. Significance is defined as $\mathrm{p}<0.05$.

\section{Discussion}

Since the cartilage defects due to lack of blood vessels and nerves cannot repair spontaneously, tissue engineering can provide the possibility of achieving to cartilage (25). Adult mesenchymal stem cells have the potential for growth and differentiation to the chondrocyte (12). The previous studies have clearly shown that MSC inhibit T-cell responses induced by mitogens and alloantigens (26). Therefore, they are the ideal candidates for cartilage tissue regeneration (12). MSC isolated from several types of tissues have the potential to differentiate into mesoderm cell lineages, especially chondrocytes (26-28). In a recent study, several types of MSCs, derived from adipose tissue, bone marrow, were encapsulated in fibrin hydrogel with TGF- $\beta 3$ and then evaluated for their differentiation capacity (19). The results showed that of all three types of MSCs, cartilage cells were produced $(19,28)$. ADMSCs in comparison with bone marrow MSCs have several advantages including feasibility of harvesting in a large amount with a simple, repeatable, and minimally invasive method, the high frequency of MSCs, fast and easy expansion in culture, and higher passage cells still retaining stem cell phenotypes and pluripotency (29-31). In addition, the main benefits of ADMSCs compared with bone marrow mesenchymal stem cells are less effect of age or morbidity of patients on quality (32-34). The several experimental studies suggest that ADMSCs reduce hypertrophy and dedifferentiation of chondrocytes, protect against joint destruction, and decrease the development and prog- ress of osteoarthritis (35-38). Our results are also consistent with previous research and show that ADMSCs are an appealing source for the treatment of osteoarthritis. Therefore, considering the numerous benefits of using ADMSCs, in the present study, they were used as the cell source. In this study, we corroborated the previous findings that ADMSCs cells can differentiate into cartilage under defined culture conditions. The researches have shown that the cell's response to chondrogenic mediators may depend on the physical and biological properties of scaffold. Considering the previous studies, the subject is quite apparent that the scaffold selection influences the growth and differentiation of adult stem cells (39). Fibrin is a natural scaffold which can be applied autologously and has an important role in angiogenesis as well as having biodegradability and biocompatibility. In addition, it can achieve high seeding efficiency and uniform cell distribution. Due to the hydrophilic nature of fibrin and high amounts of water, it can be used as appropriate extracellular material for providing cell growth (19). Therefore in this study, the ability of fibrin to maintain cell viability was assessed to detect a suitable environment for inducing chondrogenic differentiation in ADMSCs. The results of MTT assay showed that the survival ability of cells in fibrin scaffold compared to controls increased significantly (Fig. 2). The following results are supporting for our review:

In a study Pelaez et al. (39) the capability of fibrin hydrogels to support chondrogenesis of bone marrow mesenchymal stem cells was evaluated. This study confirmed the suitability of fibrin hydrogel for supporting chondrogenesis and improved viability, proliferation and chondrogenic differentiation. Also, in a study conducted by Ho et al. (40) fibrin was introduced as an optimized environment promoting chondrogenesis of ADMSCs in vitro (40). Various methods are used to prove the existence of cartilage in obtained structures resulted of chondrogenic differentiation induction (41). As it has been stated in many studies, evidence suggests that the chondrogenesis, by increasing the expression and accumulation of collagen type II and aggrecan is known and TGF- $\beta$ can also be effective on Chondrogenesis (42-44). Previous studies demonstrated that TGF- $\beta 3$ led to significantly higher collagen type II expression of ADMSCs $(4,12)$.

In this research, using real time PCR technique was found that increased the expression of all genes within fibrin scaffolds was found compared to the control group $(\mathrm{p}<0.05)$. However, as seen in Fig. 5B and C, ADMSCs encapsulated in fibrin a highly the enhancement in expression of collagen type II and aggrecan genes (as the 
chondrogenesis indicator) compared to the control group $(p<0.05)$. These results with the results of Ho et al. and Ahmed et al. were consistent (40, 43). These observations indicate that chondrogenesis induction using fibrin scaffold was successful.

\section{Conclusion}

According to the results of our study, the fibrin is an appropriate scaffold for chondrogenic differentiation of ADMSCs and to protect of these cells for growth and expand their in vitro.

\section{Acknowledgements}

This work was funded by grants from The Academic Center for Education, Culture and Research, Qom Branch, Qom, Iran.

\section{Potential conflict of interest}

authors have no conflicting financial interest.

\section{References}

1. Park JG, Lee JH, Kim JN, Kang JA, Kim KJ, Park KD, Han DK, Ahn ST, Rhie JW. Chondrogenic differentiation of human adipose tissue-derived stem cells in functional PLGA scaffolds. Tissue Eng Regen Med 2011;8:47-54

2. Wei Y, Hu H, Wang H, Wu Y, Deng L, Qi J. Cartilage regeneration of adipose-derived stem cells in a hybrid scaffold from fibrin-modified PLGA. Cell Transplant 2009; 18:159-170

3. van Osch GJ, Brittberg $M$, Dennis JE, BastiaansenJenniskens YM, Erben RG, Konttinen YT, Luyten FP. Cartilage repair: past and future--lessons for regenerative medicine. J Cell Mol Med 2009;13:792-810

4. Zhang L, Hu J, Athanasiou KA. The role of tissue engineering in articular cartilage repair and regeneration. Crit Rev Biomed Eng 2009;37:1-57

5. Howard D, Buttery LD, Shakesheff KM, Roberts SJ. Tissue engineering: strategies, stem cells and scaffolds. J Anat 2008;213:66-72

6. Mobasheri A, Kalamegam G, Musumeci G, Batt ME. Chondrocyte and mesenchymal stem cell-based therapies for cartilage repair in osteoarthritis and related orthopaedic conditions. Maturitas 2014;78:188-198

7. Chang $\mathrm{CH}$, Lin FH, Kuo TF, Liu HC. Cartilage tissue engineering. Biomed Eng Appl Basis Comm 2005;17:61-71

8. Rosenbaum AJ, Grande DA, Dines JS. The use of mesenchymal stem cells in tissue engineering: A global assessment. Organogenesis 2008;4:23-27

9. Jacobs SA, Roobrouck VD, Verfaillie CM, Van Gool SW. Immunological characteristics of human mesenchymal stem cells and multipotent adult progenitor cells. Immunol Cell Biol 2013;91:32-39
10. Gimble JM, Katz AJ, Bunnell BA. Adipose-derived stem cells for regenerative medicine. Circ Res 2007;100:1249-1260

11. Chu CR, Friel N. Chondrogenic progenitor cells and articular cartilage repair. Rheumatol Curr Res 2012;S3:006.

12. Diekman BO, Rowland CR, Lennon DP, Caplan AI, Guilak F. Chondrogenesis of adult stem cells from adipose tissue and bone marrow: induction by growth factors and cartilage-derived matrix. Tissue Eng Part A 2010;16:523-533

13. Sundelacruz S, Kaplan DL. Stem cell- and scaffold-based tissue engineering approaches to osteochondral regenerative medicine. Semin Cell Dev Biol 2009;20:646-655

14. Tsuji W, Rubin JP, Marra KG. Adipose-derived stem cells: Implications in tissue regeneration. World J Stem Cells 2014;6:312-321

15. Boehler RM, Graham JG, Shea LD. Tissue engineering tools for modulation of the immune response. Biotechniques 2011;51:239-240, 242, 244 passim

16. Chan BP, Leong KW. Scaffolding in tissue engineering: general approaches and tissue-specific considerations. Eur Spine J 2008;17 Suppl 4:467-479

17. Eyrich D. Fibrin for tissue engineering of cartilage $[\mathrm{PhD}$ thesis]. Faculty of Chemistry and Pharmacy: University of Regensburg; 2006.

18. Ahmed TA, Dare EV, Hincke M. Fibrin: a versatile scaffold for tissue engineering applications. Tissue Eng Part B Rev 2008;14:199-215

19. Ahmed TA, Hincke MT. Fibrin for encapsulation of human mesenchymal stem cells for chondrogenic differentiation. In: Hayat MA, New Jersey, editor. Stem cells and cancer stem cells. 1st ed. Dordrecht; London: Springer Netherlands; 2013.

20. Ahmed TA, Griffith M, Hincke M. Characterization and inhibition of fibrin hydrogel-degrading enzymes during development of tissue engineering scaffolds. Tissue Eng 2007; 13:1469-1477

21. Jockenhoevel S, Zund G, Hoerstrup SP, Chalabi K, Sachweh JS, Demircan L, Messmer BJ, Turina M. Fibrin gel -- advantages of a new scaffold in cardiovascular tissue engineering. Eur J Cardiothorac Surg 2001;19:424-430

22. Dew L, MacNeil S, Chong CK. Vascularization strategies for tissue engineers. Regen Med 2015;10:211-224

23. Laurens N, Koolwijk P, de Maat MP. Fibrin structure and wound healing. J Thromb Haemost 2006;4:932-939

24. Zisch AH, Schenk U, Schense JC, Sakiyama-Elbert SE, Hubbell JA. Covalently conjugated VEGF--fibrin matrices for endothelialization. J Control Release 2001;72:101-113

25. Li J, Pei M. Cell senescence: a challenge in cartilage engineering and regeneration. Tissue Eng Part B Rev 2012; 18:270-287

26. Rasmusson I, Ringdén O, Sundberg B, Le Blanc K. Mesenchymal stem cells inhibit lymphocyte proliferation by mitogens and alloantigens by different mechanisms. Exp Cell Res 2005;305:33-41

27. Tabera S, Pérez-Simón JA, Díez-Campelo M, SánchezAbarca LI, Blanco B, López A, Benito A, Ocio E, SánchezGuijo FM, Cañizo C, San Miguel JF. The effect of mesen- 
chymal stem cells on the viability, proliferation and differentiation of B-lymphocytes. Haematologica 2008;93:1301-1309

28. Park JS, Shim MS, Shim SH, Yang HN, Jeon SY, Woo DG, Lee DR, Yoon TK, Park KH. Chondrogenic potential of stem cells derived from amniotic fluid, adipose tissue, or bone marrow encapsulated in fibrin gels containing TGFß3. Biomaterials 2011;32:8139-8149

29. Jo CH, Lee YG, Shin WH, Kim H, Chai JW, Jeong EC, Kim JE, Shim H, Shin JS, Shin IS, Ra JC, Oh S, Yoon KS. Intra-articular injection of mesenchymal stem cells for the treatment of osteoarthritis of the knee: a proof-of-concept clinical trial. Stem Cells 2014;32:1254-1266

30. Kern S, Eichler H, Stoeve J, Klüter H, Bieback K. Comparative analysis of mesenchymal stem cells from bone marrow, umbilical cord blood, or adipose tissue. Stem Cells 2006;24:1294-1301

31. Zhu Y, Liu T, Song K, Fan X, Ma X, Cui Z. Adipose-derived stem cell: a better stem cell than BMSC. Cell Biochem Funct 2008;26:664-675

32. Izadpanah R, Trygg C, Patel B, Kriedt C, Dufour J, Gimble JM, Bunnell BA. Biologic properties of mesenchymal stem cells derived from bone marrow and adipose tissue. J Cell Biochem 2006;99:1285-1297

33. Mirsaidi A, Kleinhans KN, Rimann M, Tiaden AN, Stauber M, Rudolph KL, Richards PJ. Telomere length, telomerase activity and osteogenic differentiation are maintained in adipose-derived stromal cells from senile osteoporotic SAMP6 mice. J Tissue Eng Regen Med 2012;6:378-390

34. Murphy JM, Dixon K, Beck S, Fabian D, Feldman A, Barry F. Reduced chondrogenic and adipogenic activity of mesenchymal stem cells from patients with advanced osteoarthritis. Arthritis Rheum 2002;46:704-713

35. Maumus M, Manferdini C, Toupet K, Peyrafitte JA, Ferreira R, Facchini A, Gabusi E, Bourin P, Jorgensen C, Lisignoli G, Noël D. Adipose mesenchymal stem cells protect chondrocytes from degeneration associated with osteoarthritis. Stem Cell Res 2013;11:834-844
36. ter Huurne $M$, Schelbergen R, Blattes R, Blom A, de Munter W, Grevers LC, Jeanson J, Noël D, Casteilla L, Jorgensen C, van den Berg W, van Lent PL. Antiinflammatory and chondroprotective effects of intraarticular injection of adipose-derived stem cells in experimental osteoarthritis. Arthritis Rheum 2012;64:3604-3613

37. Desando G, Cavallo C, Sartoni F, Martini L, Parrilli A, Veronesi F, Fini M, Giardino R, Facchini A, Grigolo B. Intra-articular delivery of adipose derived stromal cells attenuates osteoarthritis progression in an experimental rabbit model. Arthritis Res Ther 2013;15:R22

38. Toghraie FS, Chenari N, Gholipour MA, Faghih Z, Torabinejad S, Dehghani S, Ghaderi A. Treatment of osteoarthritis with infrapatellar fat pad derived mesenchymal stem cells in Rabbit. Knee 2011;18:71-75

39. Pelaez D, Huang CY, Cheung HS. Cyclic compression maintains viability and induces chondrogenesis of human mesenchymal stem cells in fibrin gel scaffolds. Stem Cells Dev 2009;18:93-102

40. Ho ST, Cool SM, Hui JH, Hutmacher DW. The influence of fibrin based hydrogels on the chondrogenic differentiation of human bone marrow stromal cells. Biomaterials 2010; 31:38-47

41. Chung C, Burdick JA. Engineering cartilage tissue. Adv Drug Deliv Rev 2008;60:243-262

42. Xu J, Wang W, Ludeman M, Cheng K, Hayami T, Lotz JC, Kapila S. Chondrogenic differentiation of human mesenchymal stem cells in three-dimensional alginate gels. Tissue Eng Part A 2008;14:667-680

43. Ahmed TA, Giulivi A, Griffith $M$, Hincke M. Fibrin glues in combination with mesenchymal stem cells to develop a tissue-engineered cartilage substitute. Tissue Eng Part A 2011;17:323-335

44. Awad HA, Wickham MQ, Leddy HA, Gimble JM, Guilak F. Chondrogenic differentiation of adipose-derived adult stem cells in agarose, alginate, and gelatin scaffolds. Biomaterials 2004;25:3211-3222 